\title{
Elaborating Two Issues Regarding Constructivism: Structure and Science
}

\author{
Yusin Lee
}

(Yonsei University)

$\begin{array}{lll}\text { I. Introduction } & \text { Content }\rangle & \\ \text { I. Structure and Emile Durkheim } & \text { II. Constructivism and Science } \\ \text { IV. Concluding Remarks }\end{array}$

- Key Words: constructivism, structure, Emile Durkheim, science, empiricism, scientific realism.

\section{【ABSTRACT 】}

This paper seeks to address two critical issues regarding constructivism. First, it elaborates on the term structure, which is one of the most critical concepts in constructivism, yet still remains elusive. To do this, it relies on Emile Durkheim's insight. Second, I challenge the critics of constructivism. In particular, these critics contend that constructivism does not engage in science. Here I attempt to demonstrate that this contention is inappropriate. To do this, I provide a discussion of two varying philosophies of science, empiricism and scientific realism, which have dissimilar views about what might be called the theory of science.

* I would like to thank Bruce Parrott, I. William Zartman, Francis Fukuyama, Frederick Holborn, and three anonymous reviewers for their helpful comments on earlier version of this article. 


\section{Introduction}

Constructivism gained much ground in the field of international relations after the end of the Cold War.1) In the fiftieth anniversary issue of the journal International Organization (1998) several theorists such as Peter J. Katzenstein, Robert O. Keohane, and Stephen D. Krasner characterized debates between rationalism and constructivism as a central dividing line in the study of international relations. They pointed out that in the 1990s some of the major points of contestation shifted. In their words, Influenced by strong currents in economics and cultural studies, debates between rationalism and constructivism are becoming more important [than those between realist and liberal currents of theory].2) Similarly, Stefano Guzzini wrote in 2000 that What a success story! Hardly known a decade ago, constructivism has risen to the officially accredited contender to the established core of the discipline. ${ }^{3}$ )

This article examines constructivism. In particular, it attempts to refine two critical issues regarding this theory: structure and science. First, it elaborates on the term structure, which is one of the most critical concepts in constructivism, yet still remains elusive. To do this, it relies on Emile Durkheim's insight. Second, I challenge the critics of constructivism. In particular, these critics argue that constructivism does not engage in science.4) This article attempts to demonstrate that this criticism is inappropriate.

1) It must be stressed that no single variant of constructivism exists. On this point, see Alexander Wendt, Social Theory of International Politics (Cambridge and New York: Cambridge University Press, 1999), pp. 3-4; Emanuel Adler, Seizing the Middle Ground: Constructivism in World Politics, European Journal of International Relations, 3(3) (1997), pp. 335-336; John G. Ruggie, What Makes the World Hang Together? Neo-utilitarianism and the Social Constructivist Challenge, International Organization, 52(4) (1998), pp. 881-882; Steve Smith, Foreign Policy Is What States Make of It: Social Construction and International Relational Theory, in Vendulka Kubalkova, Nicholas Onuf, and Paul Kowert, eds., International Relations in a Constructed World (Armonk, NY and London: M. E. Sharpe, 1998), pp. 40-41; and Maja Zehfuss, Constructivism in International Relations: The Politics of Reality (Cambridge and New York: Cambridge University Press, 2002), pp. 2-10.

2) Peter J. Katzenstein, Robert O. Keohane, and Stephen D. Krasner, International Organization and the Study of Politics, International Organization, 52(4) (1998), pp. 645-685 reprinted in Katzenstein, Keohane, and Krasner, eds., Exploration and Contestation in the Study of World Politics (Cambridge, MA and London: MIT Press, 1999), p. 43.

3) Stefano Guzzini, A Reconstruction of Constructivism in International Relations, European Journal of International Relations, 6(2) (2000), p. 147. On this point, see also Smith, Wendt's World, Review of International Studies, 26(1) (2000), p. 151; and Jeffrey T. Checkel, Social Constructivism in Global and European Politics: A Review Essay, Review of International Studies, $30(2)(2004)$, p. 229.

4) See, for instance, Michael C. Desch, Culture Clash: Assessing the Importance of Ideas in Security Studies, International Security 23(1) (1998), pp. 152-153; Keohane, Ideas Part-Way Down, Review 


\section{Structure and Emile Durkheim}

Constructivism significantly broadens Kenneth N. Waltz's definition of structure.5) Waltz justifies his restrictive definition of structure by saying that his priority is parsimonious explanations.6) Yet several analysts point out that Waltz's concept of structure has deficiencies. His sole focus on material components of structure is a case in point.7) Waltz's structure refers to the material configuration or arrangement of units in a system, namely, the distribution of capabilities under anarchy. This structure is the source of constraint on states' behavior. Waltz holds that once structure forms, it shapes and shoves states' behavior in the same way that a market becomes a force in itself, and a force that the constitutive units acting singly or in small numbers cannot control.8)

Waltz's material structure, however, cannot explain much. This is probably the reason why a student of neorealism, Stephen M. Walt, introduces the balance of threat theory. Walt's theory heavily relies on Waltz's insight. Yet the former considers the ideational factor, especially the perception of threat, as a variable that competes with others such as material capabilities and geographical proximity.9) Moreover, as Alexander Wendt

of International Studies 26(1) (2000), p. 126.

5) One primary reason why I begin the discussion with Waltz's definition of structure is that his definition has become a standard among IR analysts. In the words of Alexander Wendt, Ask most contemporary IR scholars how they would conceptualize the structure of the international system, and they will reflexively say 'distribution of capabilities'; it has become part of the common sense of the field. See Wendt, On the Via Media: A Response to the Critics, Review of International Studies 26(1) (2000), p. 167.

6) It must be stressed, though, that Waltz partially acknowledges the possibilities of broadening his concept of structure. He states that one might ask why the distribution of capabilities across states should be included in the definition of structure and not other characteristics of states that could be cast in distributional terms. The simple answer is that an international-political system is one of self-help. In a self-help system state behavior varies more with differences of power than with differences in ideology, in internal structure of property relations, or in governmental form. In self-help systems, the pressures of competition weigh more heavily than ideological preferences or international political pressures. See Kenneth N. Waltz, Reflections on Theory of International Politics: A Response to My Critics, in Robert O. Keohane ed., Neorealism and Its Critics (New York: Columbia University Press, 1986), p. 329.

7) On this point, see Wendt, Social Theory of International Politics, p. 16, 20, 184; Paul Kowert, Agent versus Structure in the Construction of National Identity, in Vendulka Kubalkova, Nicholas Onuf, and Paul Kowert, eds., International Relations in a Constructed World (Armonk, NY and London: M. E. Sharpe, 1998), p. 103; Robert Jervis, System Effects: Complexity in Political and Social Life (Princeton, NJ: Princeton University Press, 1997), p. 109.

8) Waltz, Theory of International Politics, (Reading, Massachusetts: Addison-Wesley, 1979), p. 90.

9) Stephen M. Walt, The Origin of Alliances (Ithaca and London: Cornell University Press, 1987), pp. 21-26. In this respect, according to Peter J. Katzenstein, Walt's balnce of threat theory is a substantial departure from Waltz's neorealism. See Katzenstein, Introduction: Alternative Perspectives on National Security, in Peter J. Katzenstein ed., The Culture of National Security: 
suggests, Waltz's material structure cannot explain why the threat posed to the United States by five North Korean (possible) nuclear weapons is greater than that posed by five hundred British ones. This is so because Waltz's structure does not take into account the ideational factor: the British are friends and the North Koreans are not. ${ }^{10)}$

Therefore, it is necessary to follow Emile Durkheim's insight.11) Even though Waltz's structural theory is indebted to Durkheim, the former leaves out much of the latter's concept of structure.12) In Durkheim's view, social facts or the sources of constraint consist of ways of acting, thinking, and feeling, external to the individual, and endowed with a power of coercion, by reason of which they control him. ${ }^{13)}$ Durkheim provides examples of the sources of constraint. He writes that $\cdots$ the public conscience exercises a check on every act which offends it by means of the surveillance it exercises over the conduct of citizens. In many cases the constraint is less violent. But nevertheless it always exists. The constraint is efficacious for being indirect. I am not obliged to speak French with my fellow-countrymen nor to use the legal currency, but I cannot possibly do otherwise. If I tried to escape this necessity, my attempt would fail miserably. ${ }^{14)}$ As David Dessler points out, Durkheim's beliefs and practicesway of acting, thinking, and feeling are not necessarily material characteristics, but ideational ones, constituted by the subjective and intersubjective meanings held by actors [agents]. ${ }^{15)}$

Waltz leaves out these ideational components from his definition of structure. This is so, Dessler notes, despite the fact that Waltz's own analysis seems to support Durkheim's insight. 16) For instance, in his analysis of the effect of a change in structure on the relative stability of European politics after World War II, Waltz says that the dynamics of political relationships among European states became different in quality after World War II because the international system shifted from a multipolar to a bipolar one.17) Therefore,

Norms and Identity in World Politics (New York: Columbia University Press, 1996), p. 27.

10) Wendt and Daniel Friedheim, Hierarchy under Anarchy: Informal Empire and the East German State, International Organization 49(4) (1995), p. 692.

11) Even though Waltz's structural theory is indebted to Durkheim, the former leaves out much of the latter's concept of structures. See Ruggie (1998) What Makes the World Hang Together? Neo-utilitarianism and the Social Constructivist Challenge, p. 857.

12) Ruggie, What Makes the World Hang Together? Neo-utilitarianism and the Social Constructivist Challenge, p. 857.

13) Emile Durkheim, The Rules of Sociological Method, $8^{\text {th }}$ edition (New York: The Free Press, 1964), p. 3.

14) Ibid., pp. 2-3.

15) David Dessler, Structural Origins of Major War (Baltimore, MD: Ph.D. Dissertation, The Johns Hopkins University, 1987), p. 26.

16) Ibid., p. 27.

17) Waltz, Theory of International Politics, p. 71. 
we would expect Waltz to attribute the newly found stability of European politics to the change in the distribution of capability alone in the international system. Yet his explanation suggests otherwise. Waltz writes that Living in the superpowers' shadow, Britain, France, Germany and Italy quickly saw that war among them would be fruitless and soon began to believe it impossible. Because the security of all of them came to depend ultimately on the policies of others, rather than on their own, unity could effectively be worked for, although not easily achieved. Conflicts of interest remain, but not the expectation that someone will use force to resolve them.18) This explanation, according to Dessler, clearly indicates that it is not the material distribution of capabilities per se, but the concrete configuration of beliefs, practices, and expectations that constrains outcomes. ${ }^{19)}$

Waltz's explanation of the creation of bi-polarity after World War II is not much different. According to Rey Koslowski and Friedrich V. Kratochwil, Waltz explains the creation of bi-polarity not by looking at the distribution of capabilities per se, but by pointing to the practices between the United States and the Soviet Union.20) Waltz states that Crises are produced by the determination of a state to resist a change that another state tries to make. Communist guerrillas operating in Greece prompted the Truman Doctrine. The tightening of the Soviet Union's control over the states of Eastern Europe led to the Marshall Plan and the Atlantic Defense Treaty. The plan to form a West German government produced the Berlin blockade. And so on through the 1950's, 60's and 70's. Our responses are geared to the Soviet Union's actions, and theirs to ours, which has produced an increasingly solid bipolar balance. ${ }^{21)}$

Thus, it is necessary to broaden Waltz's definition of structure. Durkheim contends that the sources of constraint on individual behavior lie in social practices. If we extend this insight to international relations, according to Dessler, we can infer that the sources of constraint are not the distribution of power per se, but the associated structure of practice s. ${ }^{22)}$ In short, structure includes social practices.

To be more clear, I elaborate more on the definition of structure. In the first place,

18) Ibid., pp. 70-71 (emphasis added).

19) Dessler, Structural Origins of Major War, p. 28.

20) Rey Koslowski and Friedrich V. Kratochwil, Understanding Change in International Politics: The Soviet Empire's Demise and the International System, International Organization 48(2) (1994), pp. 231-232.

21) Waltz, Theory of International Politics, p. 171 (emphasis added).

22) Dessler, Structural Origins of Major War, p. 27. William H. Sewell defines the term structure in a similar way, even though he employs varying terms such as resources and schema. See William H. Sewell, Jr., A Theory of Structure: Duality, Agency, and Transformation, American Journal of Sociology 98(1) (1992), p. 8. 
it must be stressed that following Durkheim's insight in defining structure does not necessarily mean that constructivists ignore material components of structure. Nicholas Onuf says that many constraints on agents have a material component. In the words of Ounf, We need air to breathe; we do not have wings to fly.23) Similarly, Dessler points out that a military strategy needs military forces; monetary policy, financial instruments; trade policy, the goods and physical infrastructure of trade. ${ }^{24)}$ This is the primary reason why the degree of freedom that agents possess depends substantially on structures. As Wendt notes, Militarily weak states typically cannot conquer powerful ones, powerful states typically can conquer weak states. Armies with tanks will usually defeat armies with spears. ${ }^{25)}$ Likewise, William H. Sewell suggests that the president of the United States has more power over global environmental policy than the president of Turkmenistan. ${ }^{26)}$

Moreover, structure should be understood as not only constraining but also enabling. ${ }^{27)}$ This point becomes clear with some examples. For instance, the American currency constrains people in the United States to use that currency, but the currency at the same time enables people to conduct commercial transactions. The same is true for language. As Dessler points out, the relation of action to structure is analogous to that of speech to language. He notes that language, as a set of semantic and syntactic rules, makes the very act of speech or communication possible. Yet it simultaneously constrains the ways that the act of speech can be effected. In other words, the rules of language make it possible to speak sensibly, and they put limits on what counts as sensible speech. ${ }^{28}$ )

Furthermore, structures include many elements that Waltz may not include in his definition of structure. Waltz, for example, does not consider alliances as structure because they are products of actions between agents, or to be more precise, interactions between agents.29) Waltz is very sensitive about conflating units and system. He is specific in pointing out that structure does not include the attributes of units and their interaction. ${ }^{30}$ )

23) Nicholas Onuf, Constructivism: A User's Manual, in Vendulka Kubalkova, Nicholas Onuf, and Paul Kowert, eds., International Relations in a Constructed World (Armonk, NY and London: M. E. Sharpe, 1998), p. 64. On this point, see also Adler, p. 323; Wendt, Constructing International Politics, International Security 20(1) (1995), p. 73; Wendt, Social Theory of International Politics, p. 23.

24) Dessler, What's at Stake in the Agent-Structure Debate, International Organization 43(3) (1989), p. 453.

25) Wendt, Social Theory of International Politics, pp. 110-111.

26) Sewell, p. 21.

27) On this point, see Sharon Hays Structure and Agency and the Sticky Problem of Culture, Sociological Theory 12(1) (1994), p. 61.

28) Dessler, What's at Stake in the Agent-Structure Debate, p. 452.

29) Waltz, Theory of International Politics, p. 98.

30) Ibid., pp. 79, 98 
Waltz suggests that alliances are simply aspects of interaction. To be sure, he says that although relations defined in terms of interactions must be excluded from structural definitions, relations defined in terms of groupings of states appear to indicate something about how states are placed or arranged in the system.

Nevertheless, he is quick to point out that alliances are merely a feature of the accommodations and conflicts that may occur within them or groupings that may now and then form. Thus, Waltz argues that to include alliances in the definition of structure is like defining domestic political structure partly in terms of how presidents and prime ministers are related to other political agents. In his words, parts of a government may draw together or pull apart, oppose each other or cooperate in greater or lesser degree. These are relations that form and dissolve within a system rather than structural alteration s. ${ }^{31)}$ In short, according to Dessler, Waltz suggests that alliances are not structure because they indicate how units relate to one another (how they interact), not how they stand in relation to one another (how they are arranged or positioned.) $)^{32}$ )

Dessler persuasively challenges this point. He notes that alliances truly emerge from state interaction. Yet he stresses that they are not simply aspects of that interaction but products of it. ${ }^{33)}$ In other words, alliances are not just groupings between states, reducible to unit-level interactions. Rather, they are real structures, sedimented deposits that become conditions of subsequent interaction. Dessler points out that NATO is a prime example of real structure. In his words, NATO rather than being just an aspect of the (unit-level) interaction among a select number of states is a real (system-level) structure of rules that regulates and gives meaning to a wide range of current and contemplated behavior by those states. ${ }^{34)}$

I provide one more example to clarify the concept of structure and to illustrate how structure constrains/enables state's behavior. As Dessler suggests, Waltz's example of Soviet behavior shortly after the Russian Revolution in 1917 well demonstrates the role of structure. The Bolsheviks advocated international revolution and denounced the convention of diplomacy. They in effect asserted that we will not be socialized to this system. Yet they realized that in a competitive arena, one party may need the assistance of others. Refusal to play the political game may risk one's own destruction. Under this circumstance, according to Dessler, the Bolsheviks capitulated to the prevailing system of practices. ${ }^{35)}$

31) Ibid., p. 98.

32) Dessler, What's at Stake in the Agent-Structure Debate, p. 462 . On this point, see also Wendt, Social Theory of International Politics, p. 100.

33) Dessler, What's at Stake in the Agent-Structure Debate, p. 462 (emphasis in original).

34) Ibid. 
Despite his excellent interpretation of Durkheim's concept of structure, Dessler appears to misconstrue one critical point. He points out that we should follow Durkheim's insight in order to avoid Waltz's reification of structure. ${ }^{36)}$ However, both Waltz and Durkheim reify structure. In Waltz's model, units have ontological primacy. To be more exact, structure is spontaneously generated and unintentionally formed by the interactions among units. This implies that the international system structure emerges only when states begin to interact. In the words of Waltz, No state intends to participate in the formation of a structure by which it and others will be constrained. ${ }^{37)}$ But once structure forms, it exists independently from any state's behavior. Waltz makes this clear by noting that his structure does not include how states relate with one another (how they interact). ${ }^{38)}$ According to Wendt, this is like saying that even if states behave in cooperative ways, the self-help system of anarchy remains the same. ${ }^{39}$ )

In Durkheim's model, structure has ontological primacy. Durkheim suggests that society conceived as an ensemble of structures is ontologically prior to the individual, and thus can be considered external to him. He states, for example, that 뱟 the church-member finds the beliefs and practices of his religious life ready-made at birth; their existence prior to his own implies their existence outside of himself. ${ }^{40)}$ According to Dessler, this does not necessarily mean that Durkheim conceives that society exists independent of all individuals. ${ }^{41)}$ Yet Durkheim is specific in pointing out that $A$ social fact is every way of acting, fixed or not, capable of exercising on the individual an external constraint; or again, every way of acting which is general throughout a given society, while at the same time existing in its own right independent of its individual manifestations. ${ }^{42)}$ Indeed, Durkheim reifies structure.

Critics point out this fact. For instance, Steven Lukes criticizes Durkheim's sociological method because it leaves no space for individuals' or agents' interpretations. It is ironic that even though Durkheim puts much emphasis on ideational components of structure (macro-structure), he does not consider to analyze the interpretation of the actors' world from within (micro-structure). In so doing, as Lukes suggests, Durkheim reifies structur e.43) The reification of structure implies at least an implicit conception of the relationships

35) Ibid., p. 460 (emphasis added).

36) Dessler, Structural Origins of Major War, pp. 26-27.

37) Waltz, Theory of International Politics, p. 91.

38) Ibid., p. 98.

39) Wendt, Social Theory of International Politics, pp. 146, 156.

40) Durkheim, pp. 1-2.

41) Dessler, Structural Origins of Major War, p. 21.

42) Durkheim (1964), p. 13 (emphasis in original).

43) Steven Lukes, Introduction, in Steven Lukes ed., The Rules of Sociological Method: And Selected 
between agents and structure: structure has only the reproductive requirements which agents passively implement. ${ }^{44)}$ In other words, Durkheim's model reduces agents to cleverly programmed automations.45) This conception allows only the reproduction of structure by agents but not the transformation of structure by agents. As a result, the conception cannot explain social change. Thus, while agreeing with Durkheim's insight in defining structure, constructivism does not follow Durkheim's tradition of methodological holism which reifies structure.

Indeed, one primary aim of constructivism is to deal with this reification of structure. It says that human agents make structures. ${ }^{46)}$ To be more exact, constructivism, unlike methodological holism, conceives agents as capable of not only reproducing structures but also transforming them. Yet, constructivism, unlike methodological individualism, holds that human actions take place under certain social structural conditions. Karl Marx's often-quoted aphorism well illustrates a core idea of constructivism: Men make their own history, but they do not make it just as they please; they do not make it under circumstances chosen by themselves, but under circumstances directly found. ${ }^{47)}$

\section{Constructivism and Science}

Critics suggest that constructivists do not engage in science. For instance, in his review of Wendt's Social Theory of International Politics, Keohane says that one great weakness

Texts on Sociology and Its Method (London: Macmillan Press, 1982), pp. 14-16. Lukes cites E. E. Evans-Pritchard: It was Durkeim and not the savage who made society into a god. See Lukes, p. 15.

44) Wendt, The Agent-Structure Problem in International Relations Theory, International Organization 41(3) (1987), p. 345. On this point, see also Elisa P. Reis, The Double Representation of the Actor in Theoretical Tradition: Durkheim and Weber, in Piotr Sztompka, ed., Agency and Structure: Reorienting Social Theory (Switzerland: Gordon and Breach, 1994), p. 65.

45) On this point, see Sewell, p. 2. In the words of Sharon Hays, Durkheim's model conceives agents as mere minions sent out to do the bidding of structure. See Hays, p. 62.

46) On this point, see Ruggie, What Makes the World Hang Together? Neo-utilitarianism and the Social Constructivist Challenge, p. 856; Onuf, Constructivism: A User's Manuel, p. 60; Martha Finnemore, National Interests in International Society (Ithaca and London: Cornell University Press, 1996), p. 24.

47) Quoted in Robert C. Tucker, The Marx-Engels Readers, $2^{\text {nd }}$ edition (New York: W. W. Norton \& Company Inc., 1978), p. 595. Nicholas Onuf adds more to Marx's aphorism to clarify constructivism. Onuf says that he would add at the end of the aphorism: and often with consequences they do not intend. See Ounf, A Constructivist Manifesto, in Kurt Burch and Robert A. Denemark eds., Constituting International Political Economy (Boulder and London: Lynne Rienner Publishers, 1997), p. 17. 
of this book is that it does not provide any testable prediction.48) Similarly, Michael C. Desch asserts that constructivism is not appropriate for a social science predicated on prediction. ${ }^{49)}$ Here I argue that this criticism is inappropriate by demonstrating that science is not all about prediction. As a matter of fact, two different philosophies of science, empiricism and scientific realism, have varying views about what might be called the theory of science. ${ }^{50)}$ Since comparing the two different philosophies in detail is beyond the scope of this article, I focus on contrasting two critical issues: 1) the legitimacy of ascribing ontological status to unobservable entities; 2) the nature of causal claims. ${ }^{51}$ )

The first issue that divides empiricism and scientific realism is the ontological status of unobservable entities. Empiricists equate the real with the experientially knowable. In other words, they say that entities exist only if we have direct sensory experience of them. Therefore, empiricists assert that we should be agnostic about the ontological status of unobservable entities such as quarks and utilities. ${ }^{52)}$ In contrast, according to scientific realists, we can draw inferences that those unobservable entities exist if we can observe their effects. For example, we infer the existence of quarks by observing the effects of nuclear weapons. ${ }^{53}$ )

In this respect, scientific realism better captures the actual practices of natural scientists than empiricism. Indeed, natural scientists say that viruses make people sick; gunpowder makes an explosion; a collision of air masses produces violent weather. In each of these cases, scientists assume the reality of not only a flux of observable phenomena - symptoms of disease, explosion of dynamite, and thunderstorms but also a behind-the-scene or under-the-surface particular which generates or produces those observable phenomena. ${ }^{54)}$

48) Keohane, p. 126.

49) Desch, pp. 152-153.

50) Wendt, The Agent-Structure Problem in International Relations Theory, p. 350. It must be stressed that the view I call empiricism appears in the similar form under the name of positivism. See Jack Snyder, Science and Sovietology: Bridging the Methods Gap in Soviet Foreign Policy Studies, World Politics 40(2) (1988), pp. 169-173; Martin Hollis and Steve Smith, Explaining and Understanding International Relations (Oxford: Clarendon Press, 1990), pp. 45-67; Ruggie, Constructing the World Polity: Essays on International Institutionalization (London and New York: Routledge, 1998), pp. 89-95; Rom Harre, One Thousand Years of Philosophy: From Ramanuja to Wittgenstein (Malden, MA and London: Blackwill Publishers Inc., 2000), pp. 211-221.

51) For details on the two different philosophies of science, see Harre, One Thousand Years of Philosophy: From Ramanuja to Wittgenstein, pp. 189-221; Samir Okasha, Philosophy of Science: A Very Short Introduction (New York: Oxford University Press, 2002), pp. 58-76.

52) Wendt, The Agent-Structure Problem in International Relations Theory, p. 351.

53) Ibid., p. 352.

54) Dessler, Structural Origins of Major War, pp. 39-40. On this point, see also Harre, One Thousand Years of Philosophy: From Ramanuja to Wittgenstein, p. 213. 
This behind-the-scene particular is called generative structure. In other words, a virus possesses a power which generates or produces symptoms of disease. ${ }^{55)}$

Empiricists and scientific realists also have different views on the nature of causal explanations. Empiricists explain a phenomenon by subsuming its occurrence under a law-like generalization. This explanation demonstrates that the event can be deduced from a statement of general laws together with a statement of antecedent conditions. For example, the rise of mercury inside a glass tube that has been in warm water is explained by the laws of the thermic expansion of mercury, together with the antecedent conditions of the tube's immersion in warm water. ${ }^{56)}$ Thus, the schema of the empiricist explanation is as follows: the explanandum (the column of mercury rises in the tube) is logically deduced from the explanans the initial condition (the tube's immersion in warm water) and the general law (the laws of the thermic expansion of mercury). ${ }^{57)}$

This explanation is not causal in the strict sense of the word: it does not show how a causal process works. Rather, it is correlational in that the explanation describes a succession of events: [i]f such and such events have already been observed or experienced, then so and so others may expected to occur. ${ }^{58)}$ Indeed, empiricists rely on David Hume's conception of a causal relation a constant conjunction of temporally sequenced observed events. ${ }^{59)}$ Empiricists do not go further than this because of the human inability to experience the underlying causal mechanisms between that conjunction of temporally sequenced observed events. 60 )

In contrast, scientific realism contends that we make a true explanatory claim only when we identify the underlying causal mechanisms which make a certain event naturally necessary. Dessler elaborates on this point by providing an example from meteorology: the thunderstorm. He suggests that meteorology follows the lead of scientific realism. Meteorologists begin with correlational accounts: thunderstorms occur when two air masses, one cold and dry and the other warm and humid, collide; thunderstorms are linked to hot and humid days, and to the presence of mountains; and thunderstorms are also

55) Dessler, Structural Origins of Major War, p. 42. On this point, see also Harre, The Principles of Scientific Thinking (Chicago: The University of Chicago Press, 1970), p. 10.

56) C. G. Hempel and P. Oppenheim (1948) Studies in the Logic of Explanation, Philosophy of Science 15, p. 135 quoted in Dessler, Beyond Correlations: Toward a Causal Theory of War, International Studies Quarterly 35(3) (1991), p. 344.

57) Dessler, Beyond Correlations: Toward a Causal Theory of War, p. 344. On this point, Okasha, pp. 42-43.

58) Quoted in Harre, The Principles of Scientific Thinking, p. 6.

59) Wendt, The Agent-Structure Problem in International Relations Theory, p. 353.

60) For details, see Harre, One Thousand Years of Philosophy: From Ramanuja to Wittgenstein, pp. 211-213; Okasha, pp. 50-51. 
associated with high temperatures over large bodies of water. From these correlational accounts meteorologists are not interested in establishing a law-like generalization from which they can deduce a testable prediction describing a temporal sequence of events.

Rather, meteorologists seek to identify the causal mechanisms underlying thunderstorm activity. ${ }^{61)}$ For instance, they argue that Thunderstorms occur when the adiabatic lifting process, fueled by condensing water vapor, is sufficient to overcome countervailing tendencies (e.g., the mixing of rising warm air with surrounding cool air, and the effects of cooling that result from the expansion of the rising air parcels). ${ }^{62}$ ) This explanation cannot tell when a thunderstorm will actually occur. It says that when thunderstorms occur, they can be attributed to the strength of the adiabatic lifting process; when they do not, the lifting process did not take place or was overridden by countervailing forces. ${ }^{63)}$ In short, a causal theory in scientific realism is not necessarily aimed at identifying the conditions associated with the occurrence of a specified type of outcome. This implies that the focus of the scientific realist explanation, unlike that of the empiricist explanation, is to not provide testable predictions. ${ }^{64)}$

Therefore, we should apply different standards in measuring the strength of a theory in empiricism and scientific realism. The power of a theory in the empiricist explanation is determined by its predictive capability for the class of phenomena which it is intended to explain.65) It must be stressed, though, that not all empiricist explanation is deterministic. In other words, empiricists deal with the failure of their prediction by making the general law probabilistic rather than universal. For example, we know that not every case of exposure to the measles produce contagion. What can be claimed is only that persons exposed to the measles will contract the disease with high probability. ${ }^{66}$ )

In contrast, the strength of a theory in the scientific realist explanation is decided by how well a theory's purported causal mechanism describes the working of real-world generative structure.67) For example, specific causal claims concerning adiabatic expansion can be examined by collecting data on, say, the rates at which latent heat is converted

61) Dessler, Beyond Correlations: Toward a Causal Theory of War, pp. 342-343.

62) Ibid., p. 349.

63) Ibid.

64) On this point, see Harre, One Thousand Years of Philosophy: From Ramanuja to Wittgenstein, p. 195. In empiricism, explanation and prediction are the same concept. See Okasha (2002), p. 44.

65) Hollis and Smith, p. 58. On this point, see also Okasha, p. 44.

66) Quoted in Carl Hempel, Philosophy of Natural Science (Englewood Cliffs, NJ: Prentice-Hall, 1996), Section 5.4 cited in Dessler, Structural Origins of Major War, pp. 49-50.

67) Dessler, Beyond Correlations: Toward a Causal Theory of War, p. 349. On this point, see also Wendt, Social Theory of International Politics, p. 58; Okasha (2002), p. 59. 
to sensible heat in an ascending and cooling air parcel.68) Meteorological theories, applied to an irreducibly open system ('the weather'), do not have a good reputation for high predictive power. Nevertheless, according to Dessler, many explanations of weather phenomena are considered well-established, because they provide convincing accounts of the underlying causal mechanisms. ${ }^{69)}$

Traditional IR approaches such as neorealism and neoliberalism fall between the empiricist and scientific realist explanations outlined above. All these approaches entail an element of the scientific explanation in that they examine unobservable entities such as the international system, states, and national interest. However, these traditional approaches lean toward the empiricist explanation, especially in the sense that they rely on the deductive-nomological analytical framework. ${ }^{70)}$ Joseph Grieco's neorealist theory is a case in point. Grieco, a leading neorealist, says that if the state's relative power declines, then the state's sensitivity to relative gains increases. ${ }^{71)}$ This hypothesis describes a temporal sequence of events. To be more specific, Grieco provides a testable prediction in the from of an if, then proposition. He can draw the hypothesis from the deductive-nomological generalization that the state's imperative under the anarchical international system is survival and the initial condition that the state's relative power declines. Grieco can establish a temporal sequence of events because he assumes that insiders or agents are rational. ${ }^{72)}$

However, as soon as we, like constructivists, begin to posit that agents are interpretive, it becomes very difficult to provide any testable prediction. For example, constructivists such as Emanuel Adler and Peter Haas contend that between international structures and human volition lies interpretation. ${ }^{73}$ ) This contention cannot offer any testable prediction since outsiders or analysts do not know a priori how agents interpret their structures. Mitchell M. Waldrop excellently explains this point by employing metaphors: Suppose you toss a rock into the air. It can make only a simple response to the external forces that act on it. But if you throw a bird into the air, it may fly off into a tree. Even though the same physical forces act on the bird as on the rock, a massive amount of internal information-processing takes place inside the bird and affects its behavior. ${ }^{74)}$ As such,

68) Dessler, Beyond Correlations: Toward a Causal Theory of War, p. 349.

69) Dessler, Structural Origins of Major War, p. 328.

70) On this point, see Wendt, Social Theory of International Politics, pp. 47-49.

71) Joseph Grieco, Cooperation among Nations: Europe, America, and Non-Tariff Barriers to Trade (Itacha and London: Cornell University Press, 1990), p. 46.

72) On this point, see Ruggie, Constructing the World Polity: Essays on International Institutionalization, p. 90; Snyder, p. 176.

73) Adler and Peter M. Haas, Epistemic Communities, World Order, and the Creation of a Reflective Research Program, International Organization 46(1) (1992), p. 367. 
analysts only ex post facto examine how agents interpreted their structure and take this interpretation as a causal variable. ${ }^{75}$ )

This may explain why critics argue that constructivism puts too much emphasis on the past. For example, Dale C. Copeland criticizes constructivism by suggesting that it is a backward-looking theory. ${ }^{76}$ ) Indeed, constructivism is not well suited to provide a testable prediction. As Ted Hopf notes, constructivism provides an understanding of a process and an outcome, but no a priori prediction per se.77)

Instead, constructivism is interested in identifying the underlying causal mechanisms between the explanans and explanandum. In this respect, it follows the lead of scientific realism. To be more clear, I compare constructivist approach especially with that of neorealist systemic theory. To claim that A (the explanans) caused B (the explanandum) is to say that there is a causal mechanism leading from the occurrence of $A$ to the occurrence of B. But the deductive-nomological analytical framework in neorealist theory is not compatible with the efforts to identify the causal mechanisms. ${ }^{78)}$ Indeed, neorealist theory does not specify the causal mechanisms. Peter J. Katzenstein calls the method of neorealist theory a three-step analysis. In his words, First, there is the specification of a set of constraints. Then comes the stipulation of a set of actors who are assumed to have certain kinds of interest. Finally, the behavior of the actors is observed, and that behavior is related to the constraining conditions in which these actors, with their assumed interests, find themselves. ${ }^{79}$ )

In contrast, constructivist approaches attempt to identify the underlying causal mechanisms by tracing a process unexplored by a neorealist approach, especially how structures shape agents' ideas and then their interests or behavior. This method of process-tracing relies on the dynamic analysis of the agent-structure relations. To be sure, constructivism does not offer any unified hypothesized causal mechanisms in the international and domestic levels of analysis. For example, some constructivists such as Wendt and Martha Finnemore focus on how international structures shape actors' ideas and then their interests or behavior.80) Other constructivists such as Katzenstein and Thomas

74) Mitchell M. Waldrop, Complexity: The Emerging Science at the Edge of Order and Chaos (New York: Simon and Schuster, 1992), p. 232 paraphrased in Adler, p. 320.

75) Adler, p. 329.

76) Copeland calls neorealism a forward-looking theory. See Dale C. Copeland, The Constructivist Challenge to Structural Realism, International Security 25(2) (2000), p. 205.

77) Ted Hopf, The Promise of Constructivism in International Relations Theory, International Security 23(1) (1998), p. 197.

78) On this point, see Wendt, Social Theory of International Politics, pp. 80-81.

79) Katzenstein, Introduction: Alternative Perspectives on National Security, p. 14.

80) Wendt, Social Theory of International Politics; Finnemore. 
U. Berger put emphasis on how domestic structures affect agents' ideas and then their interests or behavior. ${ }^{81)}$ Other constructivists such as Thomas Risse-Kappen and Audie Klotz examine the impact of how both international and domestic structures shape actors' ideas and then their interests or behavior. ${ }^{82)}$ Despite these differences in the level of analysis, however, most constructivist approaches share a similarity in that they posit that there exist structures, human agents, and their interpretations between the occurrence of A and the occurrence of B.83) By taking this method, constructivism seeks to identify the underlying causal mechanisms between the explanans (A) and explanandum (B).

\section{Concluding Remarks}

This article has examined two critical issues regarding constructivism. First, it provided a constructivist notion of structure which remains elusive at best. To do this, it followed Durkheim's insight. In the process, it demonstrated that Waltz's own analysis relies on the constructivist notion of structure. Second, I challenged the contention that constructivism does not engage in science. To do this, I illustrated that this contention is based on the misconceived notion regarding the theory of science. Indeed, one primary aim of science, according to scientific realism, is to identify causal mechanisms rather than to provide testable predictions. Constructivist approaches seek to accomplish this aim. In this respect, it is inappropriate to contend that constructivism is not suitable for science simply because it does not provide testable predictions in the from of an if, then proposition.

81) Katzenstein, Cultural Norms and National Security: Police and Military in Postwar Japan (Ithaca and London: Cornell University Press, 1996); Thomas U. Berger, Norms, Identity, and National Security in Germany and Japan, in Peter J. Katzenstein ed., The Culture of National Security: Norms and Identity in World Politics (New York: Columbia University Press, 1996).

82) Thomas Risse-Kappen, Ideas Do not Float Freely: Transnational Coalitions, Domestic Structures and the End of the Cold War, International Organization 48(2) (1994), pp. 185-214; Audie Klotz, Norms in International Relations: The Struggle against Apartheid (Ithaca, NY: Cornell University Press, 1995).

83) On this point, see Ronald L. Jepperson, Wendt, and Katzenstein, Norms, Identity, and Culture in National Security, in Peter J. Katzenstein ed., The Culture of National Security: Norms and Identity in World Politics (New York: Columbia University Press, 1996), pp. 52-63. 


\section{References}

Adler, Emanuel, Seizing the Middle Ground: Constructivism in World Politics, European Journal of International Relations, 3(3) (1997). and Peter M. Haas, Epistemic Communities, World Order, and the Creation of a Reflective Research Program, International Organization 46(1) (1992).

Berger, Thomas, U., Norms, Identity, and National Security in Germany and Japan, in

Peter J. Katzenstein ed., The Culture of National Security: Norms and Identity in World Politics (New York: Columbia University Press, 1996).

Checkel, Jeffrey T., Social Constructivism in Global and European Politics: A Review Essay, Review of International Studies, 30(2) (2004).

Copeland, Dale C., The Constructivist Challenge to Structural Realism, International Security 25(2) (2000).

Grieco, Joseph, Cooperation among Nations: Europe, America, and Non-Tariff Barriers to Trade (Itacha and London: Cornell University Press, 1990).

Guzzini, Stefano, A Reconstruction of Constructivism in International Relations, European Journal of International Relations, 6(2) (2000).

Desch, Michael C., Culture Clash: Assessing the Importance of Ideas in Security Studies, International Security 23(1) (1998).

Dessler, David, Beyond Correlations: Toward a Causal Theory of War, International Studies Quarterly 35(3) (1991).

, Structural Origins of Major War (Baltimore, MD: Ph.D. Dissertation, The Johns Hopkins University, 1987).

,What's at Stake in the Agent-Structure Debate, International Organization_43(3) (1989).

Durkheim, Emile, The Rules of Sociological Method, $8^{\text {th }}$ edition (New York: The Free Press, 1964).

Finnemore, Martha, National Interests in International Society (Ithaca and London: Cornell University Press, 1996).

Harre, Rom, One Thousand Years of Philosophy: From Ramanuja to Wittgenstein (Malden, MA and London: Blackwill Publishers Inc., 2000).

Hays, Sharon, Structure and Agency and the Sticky Problem of Culture, Sociological Theory 12(1) (1994).

Hollis, Martin and Steve Smith, Explaining and Understanding International Relations (Oxford: Clarendon Press, 1990). 
Hopf, Ted, The Promise of Constructivism in International Relations Theory, International Security 23(1) (1998).

Jepperson, Ronald L., Wendt, and Katzenstein, Norms, Identity, and Culture in National Security, in Peter J. Katzenstein ed., The Culture of National Security: Norms and Identity in World Politics (New York: Columbia University Press, 1996).

Jervis, Robert, System Effects: Complexity in Political and Social Life (Princeton, NJ: Princeton University Press, 1997).

Katzenstein, Peter J., Cultural Norms and National Security: Police and Military in Postwar Japan (Ithaca and London: Cornell University Press, 1996). Introduction: Alternative Perspectives on National Security, in Katzenstein ed.,

The Culture of National Security: Norms and Identity in World Politics (New York: Columbia University Press, 1996), , Robert O. Keohane, and Stephen D. Krasner, International Organization and the Study of Politics, International Organization, 52(4) (1998), pp. 645-685 reprinted in Katzenstein, Keohane, and Krasner, eds., Exploration and Contestation in the Study of World Politics (Cambridge, MA and London: MIT Press, 1999).

Keohane, Robert, O., Ideas Part-Way Down, Review of International Studies 26(1) (2000). Klotz, Audie, Norms in International Relations: The Struggle against Apartheid (Ithaca, NY: Cornell University Press, 1995).

Koslowski, Rey and Friedrich V. Kratochwil, Understanding Change in International Politics: The Soviet Empire's Demise and the International System, International Organization 48(2) (1994).

Kowert, Paul, Agent versus Structure in the Construction of National Identity, in Vendulka Kubalkova, Nicholas Onuf, and Paul Kowert, eds., International Relations in a Constructed World (Armonk, NY and London: M. E. Sharpe, 1998).

Lukes, Steven, Introduction, in Steven Lukes ed., The Rules of Sociological Method: And Selected Texts on Sociology and Its Method (London: Macmillan Press, 1982).

Okasha, Samir, Philosophy of Science: A Very Short Introduction (New York: Oxford University Press, 2002).

Onuf, Nicholas, A Constructivist Manifesto, in Kurt Burch and Robert A. Denemark eds., Constituting International Political Economy (Boulder and London: Lynne Rienner Publishers, 1997).

Constructivism: A User's Manual, in Vendulka Kubalkova, Nicholas Onuf, and Paul Kowert, eds., International Relations in a Constructed World (Armonk, NY and London: M. E. Sharpe, 1998).

Reis, Elisa P., The Double Representation of the Actor in Theoretical Tradition: Durkheim 
and Weber, in Piotr Sztompka, ed., Agency and Structure: Reorienting Social Theory (Switzerland: Gordon and Breach, 1994).

Risse-Kappen, Thomas, Ideas Do not Float Freely: Transnational Coalitions, Domestic Structures and the End of the Cold War, International Organization 48(2) (1994). Ruggie, John, Constructing the World Polity: Essays on International Institutionalization (London and New York: Routledge, 1998).

, What Makes the World Hang Together? Neo-utilitarianism and the Social Constructivist Challenge, International Organization, 52(4) (1998).

Sewell, William H. Jr., A Theory of Structure: Duality, Agency, and Transformation, American Journal of Sociology 98(1) (1992).

Smith, Steve, Foreign Policy Is What States Make of It: Social Construction and International Relational Theory, in Vendulka Kubalkova, Nicholas Onuf, and Paul Kowert, eds., International Relations in a Constructed World (Armonk, NY and London: M. E. Sharpe, 1998). , Wendt's World, Review of International Studies, 26(1) (2000).

Snyder, Jack, Science and Sovietology: Bridging the Methods Gap in Soviet Foreign Policy Studies, World Politics 40(2) (1988).

Tucker, Robert C., The Marx-Engels Readers, $2^{\text {nd }}$ edition (New York: W. W. Norton \& Company Inc., 1978).

Walt, Stephen M., The Origin of Alliances (Ithaca and London: Cornell University Press, 1987).

Waltz, Kenneth, N., Kenneth N. Waltz, Reflections on Theory of International Politics: A Response to My Critics, in Robert O. Keohane ed., Neorealism and Its Critics (New York: Columbia University Press, 1986).

, Theory of International Politics (Reading, Massachusetts: Addison-Wesley, 1979).

Wendt, Alexander, Constructing International Politics, International Security 20(1) (1995). , On the Via Media: A Response to the Critics, Review of International Studies 26(1) (2000).

, Social Theory of International Politics (Cambridge and New York: Cambridge University Press, 1999).

, The Agent-Structure Problem in International Relations Theory, International Organization 41(3) (1987).

and Daniel Friedheim, Hierarchy under Anarchy: Informal Empire and the East

German State, International Organization 49(4) (1995).

Zehfuss, Maja, Constructivism in International Relations: The Politics of Reality (Cambridge and New York: Cambridge University Press, 2002). 